\title{
Latin American Revolutionary Poetry and Songs
}

\author{
Benjamín Valdivia \\ University of Guanajuato (Mexico).E-mail:valdivia@ugto.mx
}

Latin America has been defined as a land which has no other possibilities than its future. Since the historic times gave to this part of the world the fate of being oppressed, all its past was an expectancy of a self-consciousness in search of identity. ¿What are we if our language and traditions were sacked by cruel conquerors? We were, from there, a search for being ourselves.

In any place and time, protest expressions are a common way in the battling to attain power. In many forms, protest is linked to the arts, as they are privileged vehicle for making a stand in favor of a specific political position, or to support an opposition. Arts are, in this connection, used to be subsidiary for an ideology, a set of assumed principles, or a desideratum sustained by some social group. In the other side, arts are ambiguous, or abstract, and need some amount of interpretation. The hermeneutic process applied to arts must cover all gaps and suppositions to complete, almost always in a verbal way, the idea; or to precise with words any lack of sense. Direct declarations or obvious elements give place to pamphletary pieces, but artists accept these if they can establish with certainty a militant proposition. In that, poetry is the best way for a fusion of the abstract realm of musicality with the direct phrasing of politics. In that case, the result is a song, transmitting concepts, but with the empowering of sounds. Martial rhythms, or traditional schemes already adapted in the basis of culture, can be a good option for composers having this purpose.

In Latin America, protest is almost a way of life, due to political conflicts, war, invasion, and submission, are continuous experiences from past centuries to present. Some philosophers, as we established before, think Latin America as a world region having a serious search for identity, since each stage of its past seems to be a destruction of any possibility of feel the life as a normal property of human beings; and seems, too, an expulsion from its proper self. Because of this historical feeling of not belonging, Latin America has only one stage for self-recovery or redemption: the future. Colonial oppression is a principal item whenever we search for a definition appliable. But, at the same time, we recognize a constant trend inside the heart of Latin America: revolutionary expressions inviting to build a better future or claiming for a transformation in a self-affirming way. For all of this, one can understand why exists a variety of artistic Latin American expressions aligned in this profound path to build a better life. Its revolutionary songs and poetry intent to service for that.

After three centuries of colonial domination, in $19^{\text {th }}$ century the independence wars of these countries were theme for several poems and popular songs. In the circle of Simón Bolívar, principal hero in South America independence, songs like contredanses, "La Vencedora" [The Victorious], and "La Libertadora" [The Liberator], were extremely popular. As was usual in those years, the poetic form known in Spanish as romance served as a compositional structure for most authors. This traditional form has eight syllables, with assonant rhyming in even verses, without limit in the quantity of them. Sometimes, composition is formed in four-verse stanzas. We can

(C) AesthetixMS 2020. This Open Access article is published under a Creative Commons Attribution Non-Commercial 4.o International License (http://creativecommons.org/licenses/by-nc/4.o/), which permits non-commercial re-use, distribution, and reproduction in any medium, provided the original work is properly cited. For citation use the DOI. For commercial re-use, please contact editor@rupkatha.com. 
find that poetic tradition as a preferred structure until present times, because of its strong basis in popular culture. There is a wide number of collections of poems about heroes and battles. A good example is Romancero de la guerra de independencia [Mexican Independence War Poems], published by Victoriano Agüeros in 1910. Let us see this fragment of Hidalgo's battle in Guanajuato:

$$
\begin{aligned}
& \text { Se oyó por fin el acento } \\
& \text { viril y fuerte de Hidalgo } \\
& \text { que la puerta del castillo } \\
& \text { señalaba a sus soldados: } \\
& \text { un heroico barretero, } \\
& \text { cual un antiguo espartano } \\
& \text { los deseos adivinó } \\
& \text { de su jefe idolatrado; } \\
& \text { y cargándose una losa, } \\
& \text { y hachón ardiente en la mano, } \\
& \text { bajo un diluvio de balas } \\
& \text { adelantóse incendiando } \\
& \text { aquella ferrada puerta } \\
& \text { que estorbábales el paso. }
\end{aligned}
$$

We can find the same sort of poems in early $20^{\text {th }}$ century, as in Mexican Revolution corridos. The corrido is a piece based on traditional romance form, almost always starting with a welcome before the narrative development of actions or thinking by a protagonist, concluding in a closing declaration. The protagonist of the corridos is a character - woman or man - in a situation in which we can appreciate heroism, or moral condition, or a dark fate. In several times they are in danger of death. Into revolutionary corridos, protagonists are the leaders of each party inside military movement, as Pancho Villa, Emiliano Zapata, and others; or common people in exemplary situations of life. In Latin America, at the same time than corridos, there were local popular rhythms for the music accompanying traditional lyrics, as cueca, zamba, chacarera, etc. In every case there is an adaptation for ideas of freedom, independence and justice crossing all along this kind of songs.

As some politicians and rulers in Latin America, during the $19^{\text {th }}$ century, were also writers and poets, we can see a close relationship between life experiences and ideas expressed in poems about social transformation. Several of those poems served after as lyrics for songs. The best model is the Cuban song Guantanamera. The name is demonym from Guantánamo region in Cuba. The music in this song comes from Spanish musical schemes usual in the first half of $18^{\text {th }}$ century, adapted in oriental Cuba and fixed at the beginning of the $20^{\text {th }}$. Lyrics have changed, since people make their own alternative traditional verses, but always including parts from Versos sencillos [Plain Verses] by Cuban revolutionary leader and writer José Martí. These lyrics are sometimes near to natural life or simple things of life, but best versions are those with selections from the following set by Martí: 
Con los pobres de la tierra

quiero yo mi suerte echar:

el arroyo de la sierra

me complace más que el mar.

Mi verso al valiente agrada:

mi verso, breve y sincero,

es del vigor del acero

con que se funde la espada.

Mi verso es como un puñal

que por el puño echa flor:

mi verso es un surtidor

que da un agua de coral.

¡Yo quiero, cuando me muera,

sin patria, pero sin amo,

tener en mi tumba un ramo

de flores, y una bandera!

No me pongan en lo oscuro

A morir como un traidor;

yo soy bueno, y como bueno

Moriré de cara al Sol.iii

After hundred years, the Guantanamera continues its path of popularity, though it has shared its revolutionary content with other human concerns. Mexican Revolution corridos are in the cultural stage even in our days, but heroes and themes seem a little old, as if memories of some ancient battle beyond our grandfathers. Nevertheless, political conflicts have been a constant source for new manifestations about freedom and justice. Fresh songs and poems cover all the $2 \mathrm{O}^{\text {th }}$ century in Latin America. Notorious authors and song composers created works that became indispensable references in revolutionary thinking exposed in these art forms.

Chilean poet and Nobel prize Pablo Neruda is the most conspicuous writer in Latin America political poetry in past century. His work is a wide travel into human suffering and the hope of an illuminated life. Some of his books are fully devoted to the revolution topic, as we can see in these few titles: España en el corazón [Spain in our Hearts] (1937), where the poet participate in favor of Spanish Republic movement with the international brigades; Canto general [A General Chant: Song of the Americas] (1950), in which, in a spectacular poetic journey, goes along the whole 
history of the Americas, from times before Columbus until later 4os in all continental latitudes; Fulgor y muerte de Joaquín Murieta [Splendor and Death of Joaquin Murieta] (1967), book in which this popular legendary figure is motive for an epic chant from a contemporary point of view; and Incitación al Nixonicidio y alabanza de la revolución chilena [Incitement to Nixoncide and Praise for the Chilean Revolution] (1973), a group of strong texts in traditional forms, proper to function as lyrics, opposing the politics of Nixon oriented to weaken Chilean socialist government. Let us look at two fragments, the first from "Los enemigos" [The Enemies], from Canto general:

Entonces, en el sitio

donde cayeron asesinados,

bajaron las banderas a empaparse de sangre

para alzarse de nuevo frente a los asesinos.

Por estos muertos, nuestros muertos,

pido castigo.

Para los que de sangre salpicaron la patria,

pido castigo.

Para el verdugo que mandó esta muerte,

pido castigo,

Para el traidor que ascendió sobre el crimen

pido castigo. ${ }^{\text {iv }}$

The second fragment is from poem, "A ti te llamo" [I Appeal to You], from Incitación al nixonicidio... [Incitement to Nixonicide...]:

te necesito, mi joven hermano,

joven hermana, escucha lo que digo:

yo no creo en los odios inhumanos,

y no creo que el hombre es enemigo:

creo que con tu mano y con mi mano,

frente al malvado y contra sus castigos,

llenaremos la Patria de regalos

sabrosos y dorados como el trigo.

Amongst poets linked with revolutionary ideals in the second half of the $20^{\text {th }}$ century we have many names as: Uruguayan Mario Benedetti, Argentinian Raúl González Tunón, Mexican Efraín Huerta, and Nicaraguan Ernesto Cardenal. All of them had personal approaches to the place of poetry in seeking a change in the world: Benedetti focuses on urban society and middle-class difficulties to accept social changes; González Tuñón is a more lyrical and imaginative communist militant; Huerta used irony as a weapon to destroy the good-mannered culture; and Cardenal had 
a compassionate questioning for society from a catholic view. There were several great writers in this trend, but the mentioned ones are recognized amongst the best.

Revolutionary poets in Latin America sometimes had not only the words but also the guns. Guerrilla poets have a particular vision, tinted by their experiences as soldiers in violent political movements. Amongst others, three of them were Salvadoran Roque Dalton, Guatemalan OttoRené Castillo, and Nicaraguan Leonel Rugama. They all died young by execution (Dalton) or in combat (Castillo) or by torture (Rugama). Their poetry is of intense lyrism whit references to combat or to like-war situations and exaltation of the homeland. Let us see those aspects in some fragments. First, from de poem, "Vida, oficios" [Life, Trades], by Roque Dalton:

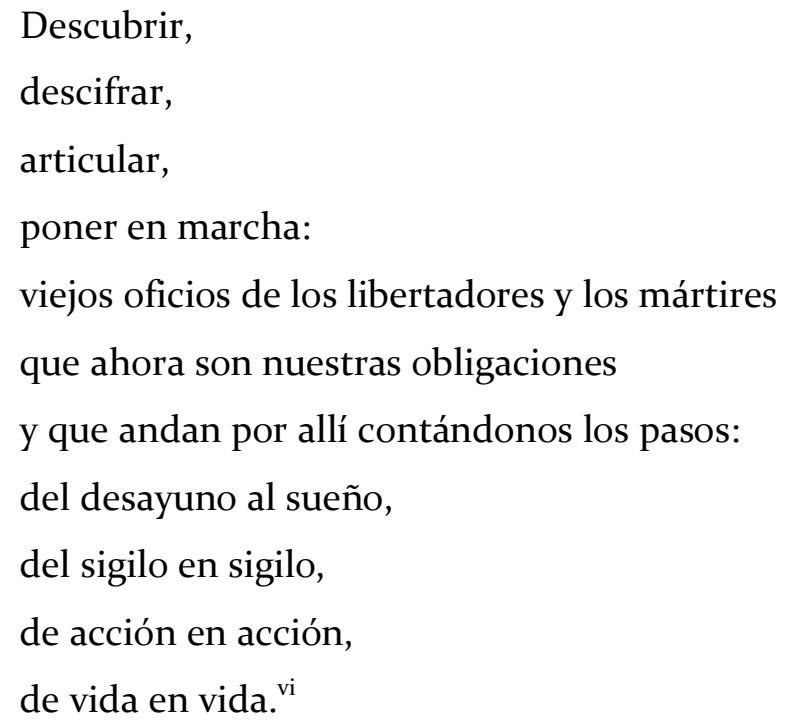

The poet says it is mandatory to be liberators and martyrs because of the trades of heroes from past times. In other direction, Otto René Castillo has a compassionate walk with the homeland, as in a song of unity, in this fragment of his poem, "Vámonos patria a caminar" [Oh my Homeland, Let us Go Walking]:

Ay, patria,

a los coroneles que orinan tus muros

tenemos que arrancarlos de raíces,

colgarlos en un árbol de rocío agudo,

violento de cóleras del pueblo.

Por ello pido que caminemos juntos. Siempre

con los campesinos agrarios

y los obreros sindicales,

con el que tenga un corazón para quererte.

Vámonos patria a caminar, yo te acompaño. ${ }^{\text {vi }}$

The other one is a fragment from poem, "Las casas quedaron llenas de humo" [The Houses Were Filled with Smoke], by Leonel Rugama, in which a few guerrilla fellows were trapped inside a house while official forces are shooting to them, who at last die like heroes: 
Las casas quedaron llenas de humo

y después de dos horas

gente sin megáfono

gritaba que se rindieran,

Mientras la tanqueta

y las órdenes

las Browning

las Madzen

las $\mathrm{M}-3$

los M-1

y las carreras

las granadas

las bombas lacrimógenas...

y los temblores de los guardias.

\section{NUNCA CONTESTÓ NADIE}

Porque los héroes nunca dijeron

que morían por la patria

sino que murieron. viii

Poetry by great writers as Neruda or by guerrilla militants is, nevertheless, an individual expression of a smaller distribution range than popular songs. Latin American revolutionary singers in the second half of $20^{\text {th }}$ century had wider reception than individual poets, in despite of their high recognition. In the 50 began a revival trend in favor of traditional folkloric music as a form of cultural resistance, in opposition to commercial and industrial products in this field. The Latin American folkloric movement had first line artists both individually, as Argentinian Atahualpa Yupanqui, and in groups, as also Argentinian ensemble "Los Chalchaleros". In a few years, folkloric music turned to an open political content, assuming new tendences and possibilities in musical structure and lyrics. This new singers and ensembles had roots in tradition but were projected to a future of hope and utopia. Most of them were linked to left-wing parties and social movements as Cuban Revolution, Chilean president Allende government, Nicaraguan Sandinism, or Salvadoran "Farabundo Martí" front, amongst others. With the time, there was a shift to combined and incorporated forms creating the Nueva trova, with exploration and invention in artistic construction beyond the original tradition started in the 505 .

In this way, there were singers with a more radical political intention than folkloric singers. Among these we have a wide landscape in experiences, from tragic circumstances leading to death in the case of Chilean singer Víctor Jara, until worldwide public success of Cuban Nueva trova 
singer Silvio Rodríguez, crossing the regional position and fame of Nicaraguan musician Carlos Mejía Godoy, conductor of "Los de Palacagüina” ensemble.

Víctor Jara composed several songs criticizing everyday life both of oppressive forces from social rulers and of common people and their hopes. He was an insightful author and vivid painter of details in each theme. For example, his piece, "Plegaria a un labrador" [Prayer to a Farm Worker] uses an analogy of Lord's prayer, but instead to the Lord, the request is addressed to a worker. Jara combines typical catholic sentences in the same song to reach a consistent religious tone. In the place where prayer says, "Thy kingdom come", in the song is "bring to us your kingdom of justice and equality". A biblical sentence, "Get up and walk" [Luke 5:23] become "Get up and see at your hands". Also, Jara uses, from popular prayer, "Hail Mary", the last verse: "now, and at the hour of our death", to finish the song with the same religious sense and words.

We can notice this connection between religious culture and some protest songs, as a commandment or mystic approach to revolution in some composers. Mejía Godoy has music for a complete catholic mass, but oriented to represent a humanized god, and making transcendent symbols more mundane. Mejía Godoy has this song about a guerrilla's tomb, whit an ingenious play: nobody knows where the tomb is, so the whole country become the tomb. Repetition in the search of this tomb functions effectively as a refrain, since the search is constant:

La tumba del guerrillero

¿dónde, dónde, dónde está?

Su madre está preguntando,

nadie le responderá.

La tumba del guerrillero

¿dónde, dónde, dónde está?

El pueblo está preguntando,

algún día lo sabrá. ${ }^{\text {ix }}$

In other direction, but in the same path of revolutionary thinking, Silvio Rodríguez is a more metaphoric and metaphysical author. Lyrics in his songs have contemporary taste and his music is conceived with a notorious vanguardism. We must consider a condition, different from other Latin American singers: Silvio Rodríguez performs from inside of a triumphant revolution, so his aim is not to impulse a particular kind of change, but a general view of future as an open possibility. This we can see in his song, "La era está pariendo un corazón" [The Era is Giving Birth to a Heart].

La era está pariendo un corazón.

No puede más, se muere de dolor

y hay que acudir corriendo

pues se cae el porvenir. ${ }^{\mathrm{x}}$

We have traced a glimpse on poets and singers in the Latin American revolutionary context. We should focus on one more aspect, because it is the most solid reference until present days in 
stablishing an iconic ideal of revolution: Argentinean Ernesto "Che" Guevara. This Cuban guerrilla leader became the most representative figure of the idealist who is capable to put in motion concrete actions for the construction of new social alternatives. More than his companion Fidel Castro, who was in charge and with the burden of administration and government, Che Guevara represented the free agent oriented to fight for ideals of social justice in other lands, as he did in Bolivia, where he died. This image of a revolutionary person without boundaries, and always going forward to make ideals a real thing, impacted on Latin America cultural figuration. In this way, Che Guevara image appeared in photography, painting, music, and, of course, in poetry. In my book Reunión de poemas al Che Guevara [Collected poems about Che Guevara], we can find around 50 prestigious poets writing on that topic. ${ }^{\text {i }}$ One of them, Mexican author Jesús Arellano, drawn in an old generation computer a poem following the shape of the famous photo of Che Guevara by Korda:

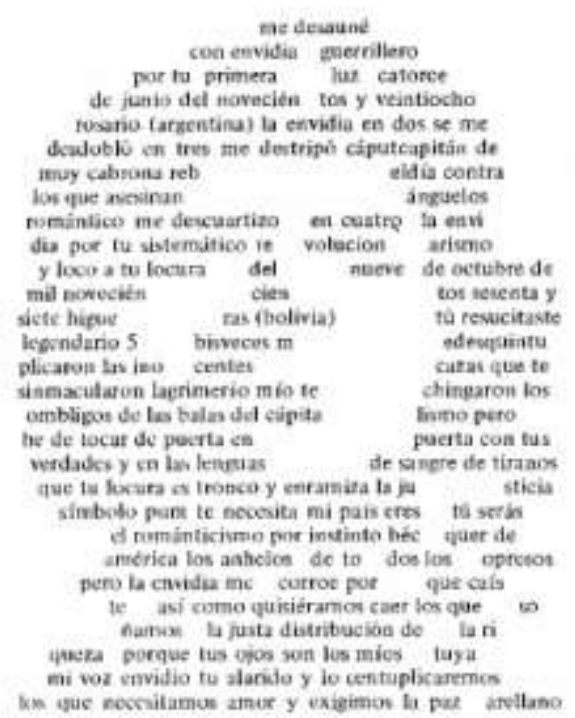

Che Guevara, as a hero and icon of Latin American revolution in the second half of $20^{\text {th }}$ century, was motive of many art works, writings, and popular songs as the well-known piece by Carlos Puebla, "Hasta siempre" [Goodbye Forever]. To finish this fast tour, we have a short poem by Argentinean Hugo de Sanctis, and a fragment from another one by Cuban major national poet Nicolás Guillén. De Sanctis made his poem, "Pasado de memoria" [The Past of Memory], he says, as a little song to the human value of one who fights to the end for his ideals:

La libertad está tan metida

adentro del pecho de América,

que la bala que incrustaron

adentro del pecho de un héroe

pensando que iba a morir,

se ha hecho raíz

en la tierra de todos nosotros. ${ }^{\text {xii }}$ 
Nicolás Guillén was a friend of Che Guevara, and from this closeness wrote his famous poem "Che Comandante" [Commandant Che Guevara, my Friend]. Let us look at this fragment:

Estás en todas partes. En el indio

hecho de sueño y cobre. Y en el negro

revuelto en espumosa muchedumbre,

y en el ser petrolero y salitrero,

y en el terrible desamparo

de la banana, y en la gran pampa de las pieles,

y en el azúcar y en la sal y en los cafetos,

tú, móvil estatua de tu sangre como te derribaron,

vivo, como no te querían,

Che Comandante,

amigo. xiii

In Latin America, revolutionary thinking is a constant. From Colonial period to independent republics, and from there to social movements in the $20^{\text {th }}$ century, and to political proposals with the aim of a change in present times, we can notice a permanent search for freedom and better conditions for people. Because of this quest, philosophers, and social analysts, have arrive to a conclusion: this is a region looking always for its future in every historic stage. As we have seen, songs and poetry have provided evidence on those ideals. Major poets and popular singers converge in this historic impulse, fighting with words and sounds, and some of them even with weapons and bullets. Revolutionary ideas, interwoven in poems and songs, are an essential presence to understand the character of Latin America, and its proper development in the totality of the world.

\section{Notes}

${ }^{i}$ The romance emerged in the Middle Ages as an evolution from Latin forms and became a solid foundation for everyday people's expression.

ii [This and the following translations into English are all originals by me specially for this paper.]

"The accent was finally heard / virile and strong from Hidalgo, / who the very castle door / pointed to his soldiers: / a heroic mining worker, / like an ancient spartan / guessed the wishes / of his idolized leader; / and carrying a slab, / and a burning torch in hand, / under a deluge of bullets / came forward and put on fire / that ironed wooden door / that hindered their way."

iii With the poor people of earth / I want my luck to cast: / the stream in the mountains / please me more than the sea. My verse pleases the brave, / my brief and sincere verse. / It is from the vigor of steel / with which the sword is tempered.

My verse is like a dagger / that from the fist blooms: / my verse is a fountain / that gives a coral water.

I want, when I die, / without a country, but without a master, / to have on my grave a bouquet / of flowers, and a flag! 
Do not put me in the dark / to die the same as a traitor: / I am a good man, and as a good man / I will die facing the Sun.

${ }^{\text {iv }}$ Then, over the very place / where they fell murdered, / they lowered the flags to be soaked in blood / to rise again in front of the assassins. / For these dead, our dead / I demand punishment.

For those who splattered with blood our homeland, / I demand punishment. / For the executioner who ordered this death, / I demand punishment. / For the traitor who rose because of this crime / I demand punishment.

${ }^{\mathrm{v}}$ I need you. my young brother, / young sister, listen to what I say: / I do not believe in inhuman hatreds / and I do not believe that man is an enemy: / I think that with your hand and with my hand, / facing the wicked and against his punishments, / we will fill the homeland with gifts, / tasty and golden like wheat.

${ }^{v i}$ Discover, / decipher, / articulate, / set in motion: / old trades of liberators and martyrs / that are now our obligations / and that are walking around counting our steps: / from breakfast to sleep, / from stealth to stealth, / from action to action, / from life to life.

vii $\mathrm{O}$ my homeland, / to the colonels who urinate your walls / we must pull them up from the roots, / and hang them on a sharp dew tree, / violent with the people's anger. / That is why I ask that we walk together. Always / with the agrarian peasants / and the union workers, / with the one who has a heart to love you. / O my homeland, let us go walking, I accompany you.

viii The houses were filled with smoke / and after two hours / people without megaphone / screamed for them to surrender, / / While the tank / and the orders / the Brownings / the Madzens / the M-3 / the M-1 / and the races / the grenades / tear-gas canisters... / and the trembling of guards. / / NO ONE ANSWERED EVER / Cause heroes never said / that they died for the homeland / rather they only died for it.

ix The guerrilla's tomb, / where, where, where is it? / His mother is asking, / no one will answer her.

The guerrilla's tomb, / where, where, where is it? / The people are asking, / one day they will know.

${ }^{\mathrm{x}}$ The era is giving birth to a heart. / She cannot take it anymore; she dies of pain / and we have to come running / because the future is falling.

${ }^{x i}$ Benjamín Valdivia (ed.). Reunión de poemas al Che Guevara. Universidad Autónoma Metropolitana, México City, 2002. ISBN 970-31-0019-8.

xii Liberty goes so deep / inside the chest of Latin America / that the bullet they drive into / the chest of a hero / thinking he was going to die / has become a root / in the soil of us all.

xiii You are everywhere. In the native people / made of dreams and copper. An in the black people / mixed up forming a sparkling crowd, / and in the workers of oil and nitrate, / and in the terrible helplessness / of the banana, and in the great pampas of the leathers, / and in the sugar, in the salt, and in the coffee trees, / you, movable statue of your blood as they knocked you down, / alive, as they did not want you, / Commandant Che Guevara, / my friend. 